\title{
Evaluation of Soft Tissue Changes in the Nasolabial and Mental Region After Class III Orthognathic Surgery: Systematic Review
}

\author{
L.Elhajoubi, A.H.Rabe, F.Zaoui, A.Halimi. \\ Corresponding author: \\ Laila elhajoubi \\ Affiliation: Ibn-Sina Hospital Center, Mohammed V University, Faculty of Dentistry, \\ Department of Dentofacial Orthopedics, Rabat, Morocco. \\ Authors: \\ Abdoul hafizou rabe, Fatima Zaoui, Halim Ali \\ Affiliation: Ibn-Sina Hospital Center, Mohammed V University, Faculty of Dentistry, \\ Department of Dentofacial Orthopedics, Rabat, Morocco.
}

doi: $10.51505 / \mathrm{ijmshr} .2021 .5203$

URL: http://dx.doi.org/10.51505/ijmshr.2021.5203

\begin{abstract}
Introduction:

Orthognathic surgery has become increasingly accepted as a method of correcting moderate to severe Class III skeletal deformities. The recognition of aesthetic factors and the prediction of the final facial profile play a very important role in the planning of surgical therapy because the majority of patients are generally very sensitive to any changes in facial aesthetics after orthognathic surgery.
\end{abstract}

\section{$\underline{\text { Objective }}$}

Evaluate soft tissue changes (Nose, lips and chin) in relation to the underlying hard tissue movements, and surgical changes after different surgical approaches, designed to treat Class III skeletal malocclusions, including different types of two-dimensional analysis and also threedimensional analysis.

\section{$\underline{\text { Materials }}$}

We adopted a research strategy based on a query of five digital bibliographic databases, PubMed, Google Scholar, and Cochrane Library over a 13-year period from 2007 to 2020 . We limited our research by using several keywords according to the following search equation: orthognathic surgery/skeletal class III/soft tissue/changes. In addition, no exclusion of articles based on language was made.

\section{$\underline{\text { Results }}$}

Orthognathic surgery in class III skeletal cases causes quite considerable changes in the facial profile and also in the overlying soft tissues, in the anterior-posterior and transverse direction. However, it has been clinically proven that the external nose undergoes more or less undesirable 


\section{International Journal of Medical Science and Health Research}

Vol. 5, No. 02; 2021

ISSN: 2581-3366

changes, mainly related to the enlargement of the alar base and nasal projection, in the context of surgical relocation of the upper jaw. While changes in the soft tissue after orthognathic surgery can be well predicted at the B-point and Pogonion point, this means that the mandibular soft tissue will be more likely to follow the underlying bone tissue. The accuracy of this prediction is not significantly affected by gender or type of orthognathic surgery.

Keywords: orthognathic surgery, skeletal class III, soft tissue, mental, naso-labial changes.

\section{INTRODUCTION}

Orthognathic surgery has optimized the treatment of Class III skeletal malocclusion, however maxillary advancement and mandibular setback or bimaxillary osteotomy are three basic options to correct these types of malocclusions. Highly reliable prediction of soft tissue outcomes plays a major role in improving treatment planning, as the majority of patients are generally very sensitive to any changes in facial aesthetics after orthognathic surgery. [1,2].

3D imaging remains a reliable and powerful tool to evaluate facial soft tissue changes that occur due to underlying skeletal movements, as it provides sufficient information about skeletal structures and accurately shows the underlying soft tissue and bone tissue simultaneously. However, the cephalogram is still a very useful means of representing hard and soft tissue structures in an image at very low radiation exposure, but it has inherent limitations in the presentation of complex 3D modifications in hard and soft tissue.

In addition, many clinicians are still not equipped with these three-dimensional technical abilities. Therefore, conventional two-dimensional radiographs offer valuable and feasible cues that should not be underestimated. [3, 4,5].

Our objective is to evaluate soft tissue changes (nose, lips and chin) in relation to the underlying hard tissue movements and surgical changes after different surgical approaches to treat Class III skeletal malocclusions, including different types of two- and three-dimensional analysis.

\section{MATERIALS}

\section{Research Strategy:}

A systematic search was conducted based on an electronic search of several databases (Pub Med, web of science, Cochrane Library) covering publications from January 2007 to December 2020. The search was conducted using the acronym PICOS, (Table 1) and limited by the use of the following keywords in English and French: orthognathic surgery / skeletal class III / soft tissue/changes. No exclusion of articles based on language was made.

\section{Selection Criteria}

\section{Inclusion criteria:}

The selection of studies was made on the basis of well-defined criteria, only randomized trials, prospective studies, retrospective studies, cohorts, case controls, in French or English language 


\section{International Journal of Medical Science and Health Research}

Vol. 5, No. 02; 2021

ISSN: 2581-3366

were selected. Only papers reporting soft tissue changes in the upper lip, lower lip, nasal and chin regions, occurring after mandibular setback, maxillary advancement, or a combination of both, were evaluated and selected for further analysis, using lateral cephalograms, or threedimensional analysis. Genioplasty cases were also included.

\section{Exclusion criteria:}

Syndromic patients and patients with severe congenital facial deformity or post-traumatic deformity, cases of facial asymmetry, cleft lip and palate, case reports, case series of less than 10 patients, descriptive studies and review articles were excluded.

\section{Data extraction}

For each article searched, we proceeded to read the titles and abstracts and even some sections (objectives, methodology) in order to determine which articles to select. This analysis was carried out in parallel by two independent evaluators. If the analysis of the title and abstract had left a doubt as to the eligibility of the bibliographic reference, it was then necessary to proceed with a complete reading of the document before including or excluding it. Studies that did not meet the inclusion criteria were rejected. After assessing eligibility, articles were analyzed and retrieved based on several parameters: year of publication, type of study, sample size, mean age and sex of patients as well as ethnicity, type of surgery (maxillary advancement, mandibular recoil, or a combination of both), and additional surgery (advanced or setback genioplasty).

\section{SEARCH RESULTS}

The search strategy initially resulted in 716 articles, while the number of abstracts selected was only 168 (Figure 1: flow chart). After reading the abstracts only 62 articles were selected for the analysis of this synthesis, out of the these articles only 18 articles were selected due to the availability of their full text, their relevance, and also their response to our eligibility criteria.

\section{Quality analysis}

The methodological quality assessment revealed that methodological validity was weak in almost all studies. (Table 2). However, they were judged to have an adequate sample size, ranging from 14 to 144 patients. In all studies, the methods used to analyze postoperative soft and hard tissue relationships were valid and well known. Using powerful statistical analyses involving paired and unpaired t-tests for statically significant change, 7 papers had deployed linear regression analysis to assess the degree of change in soft tissue relative to the underlying bone tissue, and the coefficient of determination was performed to assess the predictability of movement of the different landmarks studied and to predict changes in the areas or regions studied. However, a pearson correlation analysis in the vertical and antero-posterior direction was used in almost all studies to assess possible correlations between changes in the soft tissue and the underlying bone tissue.

Imaging acquisition and facial analysis method. (Table 3) 


\section{International Journal of Medical Science and Health Research}

Vol. 5, No. 02; 2021

ISSN: 2581-3366

\section{Three-dimensional analysis}

The studies that deployed the CBCT (Cone Beam CT Scanner), proceeded to study the movements occurring on underlying soft and hard tissues, through superimpositions of 3D images, before and after surgery. And to evaluate these changes, the first step was to determine the volumetric changes in the facial images produced by orthognathic surgery. Pre-operative and post-operative CBCT images were superimposed, using the surface recording method on the cranial base, which was stable and unaffected by the surgery. After the recording, the preoperative and postoperative $3 \mathrm{D}$ soft and hard tissue images were subtracted, to have volumetric differences.

\section{Two-dimensional analysis:}

In all studies using two-dimensional analysis (lateral cephalograms, 2D photogrammetry) to evaluate changes after skeletal class III surgical treatment, a horizontal reference line was constructed $7^{\circ}$ below the line $(\mathrm{S}-\mathrm{N})$, and a plane perpendicular to this reference line passing through the $\mathrm{N}$ point (Nasion) was used as a vertical line. The pre-and post-operative distance from each landmark to these reference lines was measured in millimetres and the differences were therefore considered as a postoperative change.

\section{DISCUSSION}

This systematic review was designed to treat soft tissue changes in different regions: nasal, mental and labial regions after different approaches (mono-maxillary, bimaxillary) used to treat a class III malocclusion of skeletal origin. Also, to identify the relationship between soft tissue change and the nature of underlying bone movement.

\section{Labial region:}

In all of the studies included in this synthesis, the same tissue reactions were observed in the lower lip region regardless of the type of intervention performed (BSSO or bimaxillary), materialized by eversion of the lower lip with a setback in the antero-posterior direction, reduction in thickness and also a decrease in the length of the lower vermilion. However, the upper lip experienced a retraction with a decrease in thickness and width, while an increase in the length of the upper vermilion, [6] was noted in only one study, due to the decrease in tension of the lower lip, which allowed the replacement of the upper lip on the lower lip, and a possible opposite change in the length at the edge of the vermilion.

While the height of the lips in the vertical direction has only been evaluated by the study of seung and al. [6], they explain that the position of the lower lip, would be influenced by the position of the upper incisors after mandibular setback surgery. In addition, the tension of the lower lips could be reduced after surgery and possibly lead to a decrease in their height. These results are consistent with those of Hershey and Lim [7,8]. However, the change in the vertical direction is still difficult to predict. Robinson et al, Jung et al reported that soft tissue changes did not closely follow hard tissue changes in the vertical plane relative to the anteroposterior and transverse planes $[9,10]$. 


\section{International Journal of Medical Science and Health Research}

Vol. 5, No. 02; 2021

ISSN: 2581-3366

Maxillary advancement caused prominence of the upper lip, with forward movement, increased thickness and also length of the upper vermilion, with ratios varying between studies in response to the amount of underlying bone movement, the study by Andris and al. showed a decrease rather than an increase in the thickness of the upper lip in relation to bimaxillary surgery, the same finding reported by L'Tanya and al.(11), 5 years after surgery, regardless of the procedure applied, which is correlated with the phenomenon of aging. While the lower lip has experienced a decrease in thickness but which remains non-statically significant. $[12,13,14,15,16,17,18$, $19,20]$.

The correlation analysis showed a statistically significant change between sex and soft tissue thickness in the upper lip area, which was smaller in men [12], and more pronounced changes in the upper lip soft tissue in women. Mobarak et al [21]. Tanya L et al [11] reported thinning associated with downward movement of the lips relative to the teeth, so that the appearance of the maxillary incisor decreases and that of the mandibular incisor increases with an apparent lengthening of the underside and flattening of the upper lip in the side view. In men, the profile straightens and the lips become more retractable. On the other hand, the profile, in women, does not straighten and the lips do not become more retracted. Soft tissue thickness and preoperative morphology have also been studied by ghassmi et al. [14, their results revealed associations between preoperative upper and lower lip thickness and net thickness change, in the sense that the greater the preoperative soft tissue thickness, the less predictable the change. However, the correlations between preoperative soft tissue thickness and net change in soft tissue thickness were too low to provide clinically useful predictions.

\section{Nasal and paranasal region:}

Most of the studies included in this synthesis showed an increase in alar base width [16,17,22], which was statically significant after advanced jaw surgery, while an increase in the nasolabial angle was found in 3 studies $[13,16,18]$, related to bimaxillary surgery, which was mainly related to the increase in distance (ENA-GN). While a decrease in the nasolabial angle was reported in 3 articles but remains non-statically significant, which is correlated with nasal morphology which differs according to the ethnic origin of patients. [14, 17, 22].

A forward projection of the nasal tip regardless of the type of intervention performed was reported in almost all the studies except for the study by junho et al, [22] which found less displacement of the nasal tip after bimaxillary or advanced maxillary surgery, thanks to the suturing of the wing strap considered to prevent or reduce the effect of its inevitable postoperative enlargement, which led to a kind of reduction in the projection of the nasal tip. Another very important factor that may be involved is the soft tissue adaptation process after surgery. Davors et al. [12] found a statically significant decrease in relation to sex and soft tissue thickness in the area under the nose with a ratio of $80 \%$ to $95 \%$ relative to bimaxillary surgery. Among others Kyung-A-Kim and al. [23] reported no statically significant changes in relation to mandibular setback surgery. 


\section{International Journal of Medical Science and Health Research}

Vol. 5, No. 02; 2021

ISSN: 2581-3366

Our study reveals that maxillary advancement, or bimaxillary surgery, has a significantly greater impact on postoperative nasolabial projection and transverse nasolabial dimensions. Subsequent enlargement of the nose is often considered an undesirable aesthetic change. The initial shape of the nose and the degree of jaw advancement must be taken into account when planning the operation. [22,24] We recommend that particular attention be paid to patients with unfavorable preoperative nasolabial parameters.

The morphological prediction and understanding gained from our 3D results allow appropriate advice regarding the potential for improvement or worsening of the nasolabial shape, with particular attention to the Le Fort1 procedure subtypes (segmented, mono-block) [16] In addition to the usual information provided prior to surgery. The patient's attention should therefore be drawn to the fact that the morphology of the external nose changes postoperatively and that surgical correction of the nose may become necessary later [25, 26]. Only a thorough understanding of the impact of orthognathic procedures on the 3D nasal morphology allows a personalized treatment plan to obtain the best aesthetic results. Patient counseling and postoperative prediction planning will be considerably more reliable today and in the future by using 3D analysis tools. [27, 28,29].

In addition, soft tissue closure techniques (wing base suturing and their various modifications) play an important role in establishing the aesthetic proportions and dimensions of the face after skeletal movement. More attention should be paid to this in the daily routine. [16].

\section{Mental and sub-mental region:}

The results were generally identical with some differences, but not significant. In all the studies involving surgery of the mandibular base, there was a movement in the antero-posterior direction at point $\mathrm{B}$, and at the Pog point, with a decrease in mandibular prognathism, accompanied by an increase in soft tissue thickness in the chin region, associated with deepening of the labio-chin fold, however, the study by Kym A-Kim,[23] reported skin receding at B, Me, and Pog, and the study by Hélcio-tadeu [19] did not identify any statically significant change in relation to a maxillary procedure. Based on these results, we can conclude that soft tissue movements around the mandible tend to accompany the underlying bone movement with ratios ranging from $73 \%$ to 97\% depending on the studies. [17, 30, 31,32].

\section{LIMITATIONS:}

The results noted during this synthesis were highly variable, making it very difficult to come out with fairly conclusive and exploitable results, this is due on the one hand to the use of different imaging and analysis methods (conventional cephalometry, cone beam scanner, 2D and 3D photogrammetry), on the other hand, the degree of skeletal shift (class III moderate, severe), the combination of several surgical approaches (fort1, BSSO, genioplasty), the amount of bone displacement that will directly influence the response of the corresponding overlying soft tissue, and also the tone, posture and muscle traction that differ from one individual to another. 


\section{International Journal of Medical Science and Health Research}

Vol. 5, No. 02; 2021

ISSN: 2581-3366

\section{CONCLUSION:}

From the results of our systematic review, it can be concluded that, Soft tissue changes after orthognathic surgery can be well predicted for soft tissue at the B-point and Pogonion point, meaning that the mandibular soft tissue will be more likely to follow the underlying bone tissue. The accuracy of this prediction is not significantly influenced by gender or type of surgery.

While, the repositioning of the maxilla changes the shape and position of the upper lip and nose, which can be made less esthetic. Such an understanding will allow the patient to be warned in advance when detrimental nasolabial alterations are present.

\section{References}

1- Rustemeyer J, Martin A. Soft tissue response in orthognathic surgery patients treated by bimaxillary osteotomy: cephalometry compared with 2-D photogrammetry. Oral Maxillofac Surg. 2013;17(1):33-41.

2- Kinzinger G, Frye L, Diedrich P. Class II treatment in adults: comparing camouflage orthodontics, dentofacial orthopedics and orthognathic surgery--a cephalometric study to evaluate various therapeutic effects. J Orofac Orthop. 2009;70(1):63-91.

3- Verze L, Bianchi FA, Schellino E, Ramieri G. Soft tissue changes after orthodontic surgical correction of jaws asymmetry evaluated by three-dimensional surface laser scanner. J Craniofac Surg. 2012;23(5):1448-52.

4. Holberg C, Schwenzer K, Rudzki-Janson I. Three-dimensional soft tissue prediction using finite elements. Part I: Implementation of a new procedure. $J$ Orofac Orthop. 2005;66(2):110-21.

5- Holberg C, Heine AK, Geis P, Schwenzer K, Rudzki-Janson I. Three-dimensional soft tissue prediction using finite elements. Part II: Clinical application. J Orofac Orthop. 2005;66(2):122-34.

6- Seung Jae Paek,1 Ji Yong Yoo,1 Jang Won Lee,1 Won-Jong Park,2 Young Deok Chee,2 Moon Gi Choi,2 Eun Joo Choi,2 and Kyung-Hwan Kwon: Changes of lip morphology following mandibular setback surgery using 3D cone-beam computed tomography images, Maxillofac Plast Reconstr Surg. 2016 Dec; 38(1): 38.

7- Lim YK, Chu EH, Lee DY, Yang IH, Baek SH. Three-dimensional evaluation of soft tissue change gradients after mandibular setback surgery in skeletal class III malocclusion. Angle Orthod. 2010 Sep;80(5):896-903.

8- Hershey HG, Smith LH. Soft-tissue profile change associated with surgical correction of the prognathic mandible. Am J Orthod. 1974 May;65(5):483-502.

9- Robinson SW, Speidel TM, Isaacson RJ, Worms FW. Soft tissue profile change produced by reduction of mandibular prognathism. Angle Orthod. 1972 Jul;42(3):227-35. 


\section{International Journal of Medical Science and Health Research}

Vol. 5, No. 02; 2021

ISSN: 2581-3366

10- Jung YJ, Kim MJ, Baek SH. Hard and soft tissue changes after correction of mandibular prognathism and facial asymmetry by mandibular setback surgery: three-dimensional analysis using computerized tomography. Oral Surg Oral Med Oral Pathol Oral Radiol Endod. 2009 Jun;107(6):763-771.

11- L'Tanya J. Bailey, a Amy Joslin Dover,b and William R. Proffi: Long-term Soft Tissue Changes after Orthodontic and Surgical Corrections of Skeletal Class III Malocclusions, Angle Orthod. 2007 May; 77(3): 389-396.

12- Davor Jokić; Dražen Jokić; Vedran Uglešić; Darko Macan; Predrag Knežević : Modifications des tissus mous après recul mandibulaire et chirurgie bimaxillaire chez les patients de classe III, Angle Orthod 2013 ; 83 (5): 817-823.

13- Mehrangiz Ghassemi a, Ralf-Dieter Hilgers b, Abdolreza Jamilian c, Abdolrahman Shokatbakhsh, Frank Hölzle: Effect of maxillary advancement on the change in the soft tissues after treatment of patients with class III malocclusion. Br J Oral Maxillofac Surg.2015 Oct; 53(8):754-9.

14-Mehrangiz Ghassemi, Alireza Ghassemi,1 Rahman Showkatbakhsh,2 Syed Sayeed Ahmad,3 Mohammad Shadab,4 Ali Modabber,1 and Abdolreza Jamilian: Evaluation of soft and hard tissue changes after bimaxillary surgery in class III orthognathic surgery and aesthetic consideration, Natl J Maxillofac Surg. 2014 Jul-Dec; 5(2): 157-160.

15- Andris Abeltins, Gundega Jakobsone: Soft tissue thickness changes after correcting Class III malocclusion with bimaxillar surgery, Stomatologija, Baltic Dental and Maxillofacial Journal. 2011;13(3):87-91.

16- Christopher R DeSesa 1, Philip Metzler 1, Rajendra Sawh-Martinez 1, Derek M Steinbacher 1: Three-dimensional Nasolabial Morphologic Alterations Following Le Fort I, Plast Reconstr Surg Glob Open. 2016 Aug; 4(8): e848.

17-Junho Jung, Chi-Heun Lee, Jung-Woo Lee, and Byung-Joon Choi: Three dimensional evaluation of soft tissue after orthognathic surgery, Head Face Med. 2018 Oct 5;14(1):21.

18- Gulnaz MARSAN, Nil CURA, Ufuk EMELKI: Soft and hard tissue changes after bimaxillary surgery in turkish female class III patients, Journal of Cranio-Maxillofacial Surgery. 2009 Jan;37(1):8-17.

19- Hélcio Tadeu Ribeiro, Ana Célia Faria, Alexandre Laguna Terreri, Francisco Veríssimo de Mello-Filho: A Cephalometric Analysis for Evaluation of Changes in Soft Tissues in the Regions of the Upper and Lower Lips and Chin due to Orthognathic Maxillary Advancement Surgery, Int Arch Otorhinolaryngol. 2014 Jan;18(1):57-62.

20- Christy John Parappallil, Ratna Parameswaran,1 Devaki Vijayalakshmi,1 and Benjamin George Thomas Mavelil: A Comparative Evaluation of Changes in Soft Tissues After Single-Jaw Surgery and Bimaxillary Surgery in Skeletal Class III Patients, J Maxillofac Oral Surg. 2018 Dec; 17(4): 538-546. 


\section{International Journal of Medical Science and Health Research}

Vol. 5, No. 02; 2021

ISSN: $2581-3366$

21-Mobarak KA, Krogstad. O Espeland. L, Lyberg.T: Factors influencing the predictability of soft tissue profile changes following mandibular setback surgery. Angle Orthod. 2001 Jun;71(3):216-27.

22-Andreas F. Hellak, Bernhard Kirsten, Michael Schauseil, Rolf Davids, Wolfgang M. Kater,2 and Heike M. Korbmacher-Steine: Influence of maxillary advancement surgery on skeletal and soft-tissue changes in the nose: a retrospective cone-beam computed tomography study; Head Face Med. 2015 Jul 9;11:23.

23-Kyung-A Kim, Ye-Jin Chang, Su-Hyun Lee, Hyun-Joon An, Ki-Ho Park: Three-dimensional soft tissue changes according to skeletal changes after mandibular setback surgery by using cone-beam computed tomography and a structured light scanner, Prog Orthod. 2019 Jul 1;20(1):25

24- Siamak Hemmatpour, Fatemeh Kadkhodaei Oliadarani, Ali Hasani, Vahid Rakhshan: Frontal-iew nasolabial soft tissue alterations after bimaxillary orthognathic surgery in Class III patients, J Orofac Orthop. 2016 Nov;77(6):400-408.

25- Leila Khamashta-Ledezma, Farhad B. Naini, and Mehmet Manisali: Review of nasal changes with maxillary orthognathic surgery, J Istanb Univ Fac Dent. 2017; 51(3 Suppl 1): S52-S61.

26- Sivabalan Vasudavan 1, Yasas S N Jayaratne, Bonnie L Padwa: Nasolabial Soft Tissue Changes After Le Fort I Advancement; J Oral Maxillofac Surg.2012 Apr;70(4):e270-7.

27 - Seung-Won Seo, Young-Soo Jung, Hyoung-Seon Baik: Three-Dimensional Analysis of Midfacial Soft Tissue Changes After Maxillary Posterior Impaction and Intraoral Vertical Ramus Osteotomy for Mandibular Setback in Class III Patients. J Craniofac Surg .2017 Oct;28(7):1789-1796.

28- Yamada T, Mishima K, Moritani N, et al. Nasolabial morphologic changes after a Le Fort I osteotomy: a three-dimensional anthropometric study. J Craniofac Surg. 2010 Jul;21(4):1089-95.

29- Mommaerts MY, Lippens F, Abeloos JV, et al. Nasal profile changes after maxillary impaction and advancement surgery. J Oral Maxillofac Surg. 2000 May;58(5):470-5.

30- Rupperti S, Winterhalder P, Rudzki I, Mast G, Holberg C: Changes in the facial soft-tissue profile after mandibular orthognathic surgery. Clin Oral Investig. 2019 Apr;23(4):17711776.

31- Su-Kwon Kim et Su-Gwan Kim. Analysis of Soft Tissue Changes after Genioplasty in Skeletal Class III Dentofacial Deformity, Yonsei Med J. 2009 Dec 31; 50(6): 814-817.

32- Lun-Jou Lo, Jing-Ling Weng, Cheng-Ting Ho, Hsiu-Hsia Lin: Three-dimensional regionbased study on the relationship between soft and hard tissue changes after orthognathic surgery in patients with prognathism, PLoS One. 2018 Aug 1;13(8):e0200589. 


\section{Figure 1: Flow Diagram}

$$
\mathrm{N}=712 \text { abstracts identified from the electronic }
$$

\begin{tabular}{|l|l|l|}
\hline PubMed & Google Scholar & Cochrane Library \\
\hline
\end{tabular}

Elimination of literature reviews, case report, case series, synthesis review, full text not available, duplicate citations, $n=344$

Items retained for screening $n=368$

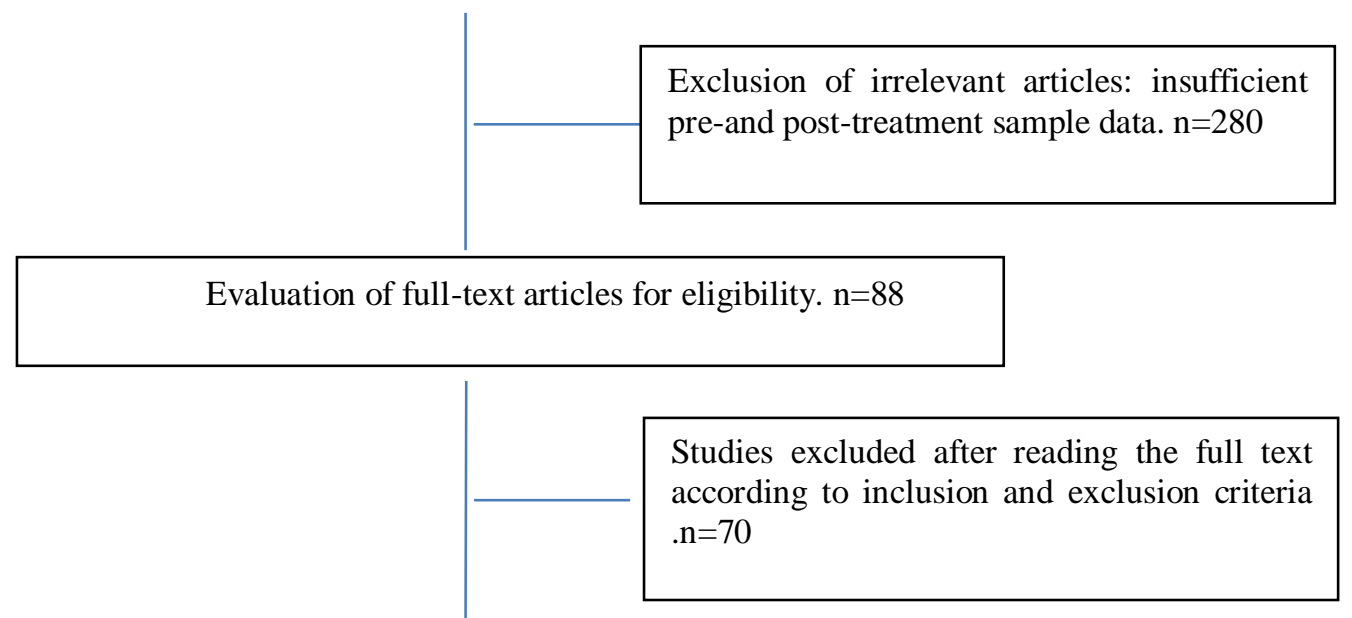

Studies included $\mathrm{n}=18$

Retrospective studie

Table 1: Picos

\begin{tabular}{|l|l|}
\hline Component & Description \\
\hline Population & Patients receiving orthognathic surgery to correct class III dysmorphosis. \\
\hline Intervention & Mono-maxillary: maxillary advance or mandibular recoil. \\
\hline Comparaison & Bimaxillary surgery. \\
\hline Outcome & Soft tissue changes (lips, nose, chin). \\
\hline Study design & $\begin{array}{l}\text { Randomized trials, prospective, retrospective studies, cohorts, control } \\
\text { cases. }\end{array}$ \\
\hline
\end{tabular}


International Journal of Medical Science and Health Research

Vol. 5, No. 02; 2021

ISSN: 2581-3366

Table 2: Author, study sample, type of malocclusion and surgical procedure

\begin{tabular}{|c|c|c|c|c|c|c|}
\hline Authors/Year & $\begin{array}{l}\text { Type of } \\
\text { study }\end{array}$ & Sample size & Meanage & Gender & Quantity of movement & Surgical procedure \\
\hline $\begin{array}{c}\text { Jan Rustemeyer } \\
\text { 2013[1] }\end{array}$ & Retrospective & 32 Patients & 23,8 Years & $\begin{array}{l}17 \text { Men } \\
15 \text { Women }\end{array}$ & $\begin{array}{l}\begin{array}{l}\text { Mand. setback }=6,6 \mathrm{~mm} \\
(\text { pointB) } \\
\text { Max.Advancement }=2,4 \mathrm{~mm}\end{array}\end{array}$ & $\begin{array}{l}\text {-BSSRO: 9Pts } \\
\text {-Advencement leFortI: 13Pts }\end{array}$ \\
\hline $\begin{array}{c}\text { Seung-Jae-Paek } \\
\text { [6] }\end{array}$ & Retrospective & 14 Patients & $\begin{array}{l}18 \text { - 29years } \\
\text { old }\end{array}$ & $\begin{array}{l}7 \text { Men } \\
7 \text { Women }\end{array}$ & $\begin{array}{l}\text { Stepback at point } B= \\
5,05 \mathrm{~mm}\end{array}$ & $\begin{array}{l}\text {-BSSRO: mandibular setback } \\
\text {-Reduction genioplasty } \\
\text {-Advanced genioplasty }\end{array}$ \\
\hline $\begin{array}{l}\text { L'Tanya J } \\
\text { 2007[11] }\end{array}$ & Retrospective & 33 Patients & $\begin{array}{c}24,3+/- \\
10 y e a r s \text { old }\end{array}$ & $\begin{array}{l}16 \text { Men } \\
17 \text { Women }\end{array}$ & $\begin{array}{l}\text { Sagittal Reposition= } \\
5.58 \mathrm{~mm}\end{array}$ & $\begin{array}{l}\text {-Advencement LefortI } \\
\text {-BSSRO: mandibular setback }\end{array}$ \\
\hline $\begin{array}{c}\text { Davor } \\
\text { Jokic'2013[12] } \\
\end{array}$ & $\begin{array}{l}\text { Cohorte } \\
\text { Retrospective }\end{array}$ & 54 Patients & $\begin{array}{l}23,5 \text { years } \\
\text { old }\end{array}$ & $\begin{array}{l}27 \text { Men } \\
27 \text { Women }\end{array}$ & $\begin{array}{l}\text { Max.Advancement }= \\
5,6 \mathrm{~mm}\end{array}$ & $\begin{array}{l}\text {-Maxillary advancement : } \\
\text { monobloc } \\
\text {-Segmented Advancement }\end{array}$ \\
\hline $\begin{array}{c}\text { Mehrangiz } \\
\text { Ghassemi } \\
2015[13]\end{array}$ & Retrospective & 35Patients & $\begin{array}{l}18 \text { à50 years } \\
\text { old }\end{array}$ & - & -Movement. < à 3mm & -Maxillary advancement. \\
\hline $\begin{array}{c}\text { Mehrangiz } \\
\text { Ghassemi } \\
\text { 2014[14] }\end{array}$ & Cohorte & 44Patients & $\begin{array}{c}28,3+/- \\
3,7 \text { years old }\end{array}$ & Women & - & $\begin{array}{l}\text {-Maxillary advancement } \\
\text { +impaction }\end{array}$ \\
\hline $\begin{array}{l}\text { Andris Abeltins } \\
\text { 2011[15] }\end{array}$ & Retrospective & 96Patients & $\begin{array}{l}\text { 25years old } \\
\quad+/-8,4\end{array}$ & $\begin{array}{l}42 \text { Women } \\
54 \text { Men }\end{array}$ & $\begin{array}{l}\text { [+] SNA: } 79,7^{\circ} \\
{[-] \text { SNB: } 83^{\circ}}\end{array}$ & $\begin{array}{l}\text {-Maxillary advancement } \\
\text {-BSSO: setback }\end{array}$ \\
\hline $\begin{array}{c}\text { Christofer R } \\
2016[16]\end{array}$ & Retrospective & 92 patients & $\begin{array}{l}24,5 \text { years } \\
\text { old }\end{array}$ & Women, Men & Movement $<2 \mathrm{~mm}$ & $\begin{array}{l}\text {-Maxillary advancement LeFort I } \\
(\mathrm{n}=48),- \text { Mandibular setback ( } \\
=12) \text {, or a combination of two } \\
\text { procedures }(\mathrm{n}=32)\end{array}$ \\
\hline $\begin{array}{l}\text { Junho-Jung } \\
\text { 2018[17] }\end{array}$ & Retrospective & 24 patients & $\begin{array}{l}18-35 \\
\text { years old }\end{array}$ & $\begin{array}{l}8 \text { Women } \\
16 \text { Men }\end{array}$ & - & $\begin{array}{l}\text {-Maxillary advancement and } \\
\text { posterior impaction and } \\
\text { mandibular setback } \\
(\text { BSSO ) }\end{array}$ \\
\hline Gu/Inaz 2009[18] & Retrospective & $\begin{array}{l}28 \text { patients } \\
\text { coréens }\end{array}$ & $\begin{array}{l}24,15 \pm \\
4,25 \text { years } \\
\text { old }\end{array}$ & $\begin{array}{l}13 \text { Men } \\
15 \text { Women }\end{array}$ & $\begin{array}{l}\text { - } 1 \text { à } 3 \mathrm{~mm} \text { : Max. } \\
\text { Advencement } \\
\text { - } 2 \text { à } 5 \mathrm{~mm} \text { : post.Impaction } \\
\text {-3 à } 12 \mathrm{~mm} \text { : mand.setback } \\
\text { - Advanced genioplasty=1 } \\
\text { à } 8 \mathrm{~mm}\end{array}$ & -BSSO: mandibular setback. \\
\hline $\begin{array}{c}\text { Hélcio Tadeu } \\
\text { Ribeiro 2013[19] }\end{array}$ & Retrospective & 18 Patients & - & - & $\begin{array}{l}\text { - mand. Setback }=5,80 \\
\mathrm{~mm} ; \\
{[-] \text { vertical }=1.64 \mathrm{~mm} \text { at }} \\
\text { the chin }\end{array}$ & $\begin{array}{l}\text {-Bi-maxillary surgery (Le Fort I } \\
\text { +BSSO) }\end{array}$ \\
\hline $\begin{array}{c}\text { Christy John } \\
\text { Parappallil } \\
\text { 2018[20] }\end{array}$ & Retrospective & 53Patients & 28years old & $\begin{array}{l}29 \text { Women } \\
24 \text { Men }\end{array}$ & - & -Maxillary advancement. \\
\hline $\begin{array}{l}\text { Andreas Fetal } \\
\text { 2015[22] }\end{array}$ & Retrospective & 83 Patients & $\begin{array}{l}25.8 \text { years } \\
\text { old }\end{array}$ & $\begin{array}{l}29 \text { Women } \\
54 \text { Men }\end{array}$ & $\begin{array}{l}\text { Gp1: Movement }<6 \mathrm{~mm} . \\
\text { Gp2: Movement }>.6 \mathrm{~mm}\end{array}$ & le fort $1+\mathrm{BSSO}$ \\
\hline $\begin{array}{c}\text { Kyung-A } \\
\text { Kim2019 [23] }\end{array}$ & Retrospective & 78patients & - & $\begin{array}{l}27 \text { Men } \\
51 \text { Women }\end{array}$ & $\begin{array}{l}\text {-Gp. A: } 3.3 \pm 2.54 .0 \pm 1.9 \\
\text { (advancement at point A) } \\
\text {-Gp. B: }-6.8 \pm 5.6-6.9 \pm 5.5 \\
\text { (Set back at point B) }\end{array}$ & $\begin{array}{l}-\mathrm{BSSO}(26) \\
-\mathrm{BSSO}+\operatorname{Lefort} 1(\mathrm{n}=52)\end{array}$ \\
\hline $\begin{array}{c}\text { Siamak } \\
\text { hemmotpoor2016, } \\
{[24]}\end{array}$ & Retrospective & 144 Patients & 17 years old & $\begin{array}{l}\text { Men and } \\
\text { Women }\end{array}$ & - & $\begin{array}{l}\text {-BSSRO: } \mathrm{n}=64 \text { Pts } \\
\text {-Bi-maxillary surgery:n= } 80 \text { Pts }\end{array}$ \\
\hline $\begin{array}{c}\text { Stéfan 2018, } \\
\text { allemangne[30] }\end{array}$ & Retrospective & 20patients & $\begin{array}{l}21,85+/- \\
1,75 \text { years } \\
\text { old }\end{array}$ & $\begin{array}{l}12 \text { men } \\
8 \text { women }\end{array}$ & $\begin{array}{l}\text { Advancement }=4,02 \mathrm{~mm} \\
\text { (Men), 3,81 mm (Women) } \\
\text { Setback= 7,71 mm (Men), } \\
6,74 \mathrm{~mm} \text { (Women) }\end{array}$ & -Bi-maxillary surgery \\
\hline $\begin{array}{c}\text { Su-Kwon Kim } \\
2009[31]\end{array}$ & Retrospective & 33Patients & $\begin{array}{c}23,4+/- \\
3,7 \text { years old }\end{array}$ & $\begin{array}{l}13 \text { men } \\
2 \mathrm{O} \text { Women }\end{array}$ & - & -Bi-maxillary surgery \\
\hline $\begin{array}{l}\text { Lun-Jou Lo } \\
\text { 2018[32] }\end{array}$ & Retrospective & 25patients & $\begin{array}{l}22,3 \text { years } \\
\text { old }\end{array}$ & $\begin{array}{l}12 \text { Men } \\
13 \text { Women }\end{array}$ & $\begin{array}{l}\text {-Advancement:4,8+/- } \\
1,7 \mathrm{~mm} \\
\text {-Setback: } 3,3+/-1,6 \mathrm{~mm} \\
\text {-Advanced } \\
\text { genioplasty:4,8mm } \\
\text {-Reduction genioplasty: } \\
\text { 3,3mm }\end{array}$ & $\begin{array}{l}\text {-Genioplasty only } \\
\text {-Genioplasty+ BSSRO } \\
\text {-Genioplasty+ BSSRO+LEFORT1 }\end{array}$ \\
\hline
\end{tabular}


Table 3: Type of imaging and analysis performed and results by region: nasal, labial and mental.

\begin{tabular}{|c|c|c|c|c|}
\hline Authors / Year & $\begin{array}{c}\text { Imaging/Analysis } \\
\text { method }\end{array}$ & Labial results & Nasal and para-nasal results & Chin area Results \\
\hline $\begin{array}{l}\text { Jan Rustemeyer } \\
\text { 2013[1] }\end{array}$ & $\begin{array}{l}\text { CBTC } \mathrm{T} 0=\text { Before } \\
\text { traitement } \mathrm{T} 1=13 \\
\text { months after }\end{array}$ & $\begin{array}{l}\text { U.L: Forward movement } \\
\text { L.L.: ant-post movement of } 66 \%\end{array}$ & $\begin{array}{l}\text {-increased alar width of } 4 \mathrm{~mm} \\
\text {-Nasal tip: less displacement, } \\
\text { Ratio=18 to } 48 \% \text {. }\end{array}$ & $\begin{array}{l}\text { Cutaneous B-point: Ant-post movement } \\
\text { of } 4.85 \mathrm{~mm} \text {. } \\
\text {-Ratio }=73 \%\end{array}$ \\
\hline Seung-Jae-Paek [6] & $\begin{array}{l}\text { Cone beam scan. } \\
\text { Lateral } \\
\text { cephalometry: T0 et } \\
\mathrm{T} 1=\text { after } 10 \mathrm{months}\end{array}$ & $\begin{array}{l}\text { [-]-Eversion and setback of L.L. of } \\
4,8 \mathrm{~mm} \\
\text { [+]Lower Vermilion length of } 19 \mathrm{~mm} \\
\text { [+]Upper Vermilion length of } 3,5 \mathrm{~mm} \\
\end{array}$ & - & $-1.2 \mathrm{~mm}$ upward displacement \\
\hline L’Tanya J 2007[11] & $\begin{array}{l}\text { CBCT } \\
\mathrm{T} 0=2 \text { weeks before } \\
\mathrm{T} 1=\text { after } 14 \text { months }\end{array}$ & - & $\begin{array}{l}+] \text { Alar width of } 2,59 \mathrm{~mm} \\
{[+] \text { Alar base of } 3,17 \mathrm{~mm}} \\
{[-] \text { Nasolabial angle: } 6.65^{\circ} .}\end{array}$ & - \\
\hline Davor Jokic'2013[12] & $\begin{array}{l}\text { 3D } \\
\text { photogrammetryT0 } \\
\text { et T1= after } 3 \\
\text { months. }\end{array}$ & -Upper lip projection. & $\begin{array}{l}{[+] \text { Nasolabial angle, Alar }} \\
\text { base width, nasal tip } \\
\text { prominence, nostril width. }\end{array}$ & - \\
\hline $\begin{array}{l}\text { Mehrangiz Ghassemi } \\
\quad 2015[13]\end{array}$ & $\begin{array}{l}\text { Lateral cephalometry } \\
\text { T0 and } \mathrm{T} 1=1 \text { year } \\
\text { later. }\end{array}$ & $\begin{array}{l}{[+] 30 \% \text { of the U.L. thickness . in }} \\
\text { the vermilion zone }\end{array}$ & - & no significant change \\
\hline $\begin{array}{c}\text { Mehrangiz Ghassemi } \\
\text { 2014[14] }\end{array}$ & $\begin{array}{l}\text { lateral cephalometry } \\
\text { (legan and burston } \\
\text { analysis) }\end{array}$ & $\begin{array}{l}\text {-extension of the U.L.: 1,6mm } \\
\text {-Rétrusion of L.L } \\
\text {-Proéminence U.L. }\end{array}$ & $\begin{array}{l}\text { [+]- the naso-labial angle } \\
\text {-Nasal tip prominence }\end{array}$ & $\begin{array}{l}{[+] \text { labio-chin furrow }} \\
{[+] \text { Total Chin }}\end{array}$ \\
\hline $\begin{array}{l}\text { Andris Abeltins } \\
\text { 2011[15] }\end{array}$ & $\begin{array}{l}\text { Lateral cephalometry } \\
\text { T0 and } \mathrm{T} 1=8 \text { weeks } \\
\text { later. }\end{array}$ & $\begin{array}{l}\text {-U.L. - line } E=\text { increase of } 2.6 \mathrm{~mm} \\
- \text { L.L- lineE=Decrease of } 0.9 \mathrm{~mm}\end{array}$ & $\begin{array}{l}{[-] \text { the naso-labial angle to }} \\
9,5^{\circ} \\
{[-] \text { nasal prominence of }} \\
18,2 \mathrm{~mm}\end{array}$ & - \\
\hline Christofer R 2016[16] & $\begin{array}{l}\text { Lateral cephalometry } \\
\mathrm{T} 1=1 \text { year } \\
\mathrm{T} 2=5 \text { years }\end{array}$ & $\begin{array}{l}\text { Maxillary advancement } \\
\text { [-] The U.L. thickness and L.L with } \\
\text { vermilion } \\
\text { Mandibular setback } \\
\text { [-] U.L. thickness of } 0.79 \mathrm{~mm} \text {, } \\
1 / 3 \text { of the patients: from } 2 \mathrm{~mm} \text { to } 4 \\
\mathrm{~mm} \\
\text { Bmaxillary: } \\
\text { [-] Thickness of U.L. }\end{array}$ & 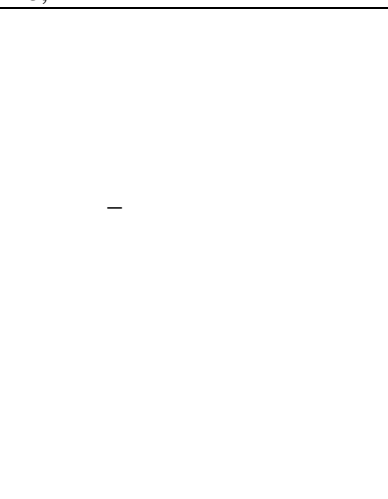 & $\begin{array}{l}\text { Maxillary advancement and } \\
\text { mandibular setback : } \\
++] \text { the thickness + prominence of the } \mathrm{Me} \text {, } \\
(2 \mathrm{~mm} \text { to } 4 \mathrm{~mm})\end{array}$ \\
\hline Junho-Jung 2018[17] & $\begin{array}{l}\text { Laterate } \\
\text { cephalometry } \mathrm{T} 0 \text { and } \\
\mathrm{T} 1=3 \text { to } 12 \text { months } \\
\text { later. }\end{array}$ & $\begin{array}{l}{[-] \text { of the thickness of the U.L.: }} \\
\text { BSSO, Bimaxillary. }\end{array}$ & $\begin{array}{l}{[-] \text { soft tissue thickness in the }} \\
\text { area under the nose (related to } \\
\text { gender) }\end{array}$ & $\begin{array}{l}{[+] \text { The thickness of the soft tissue in the }} \\
\text { area of the mentolabial sulcus and the Me }\end{array}$ \\
\hline Gu/Inaz 2009[18] & $(\mathrm{CBCT})$. & $\begin{array}{l}\text { U.L. and vermilion follow bone } \\
\text { movement }\end{array}$ & No change & $\begin{array}{l}\text { Mental region follows the corresponding } \\
\text { bone movement }\end{array}$ \\
\hline $\begin{array}{l}\text { Hélcio Tadeu Ribeiro } \\
\text { 2013[19] }\end{array}$ & $\begin{array}{l}(\mathrm{CBCT}) \text { and } \\
\text { structured light-based } \\
\text { scan. }\end{array}$ & $\begin{array}{l}{[-] \text { Of L.L. width }} \\
\text { anteroposterior direction: } \\
\text { L.L. setback. }\end{array}$ & No change & $\begin{array}{l}\text { transverse axis: changes of Me, (B ', } \\
\text { Pog', Me) Antero-post direction: } \\
\text { Receding skin markers: Me, B, Pog. } \\
\text { Vertical direction } \\
\text { upward movement of the Me. }\end{array}$ \\
\hline $\begin{array}{c}\text { Christy John } \\
\text { Parappallil 2018[20] }\end{array}$ & $\begin{array}{l}\text { Lateral cephalometry } \\
\text { T0 and T1= } 4 \text { to } 12 \\
\text { months later } \\
\text { (Legan, Burstone soft } \\
\text { tissue analysis) }\end{array}$ & $\begin{array}{l}\text { After mandibular setback } \\
++] \text { the thickness of the L.L. } \\
\text { L.L. setback. } \\
\text { After bimaxillary surgery: } \\
\text { U.L. protrusion [+] } \\
\text { protrusion L.L.[-] }\end{array}$ & No change & $\begin{array}{l}\text { Mandibular setback } \\
{[-] \text { mandibular prognathism. }} \\
\text { [-] Bimaxillary surgery: } \\
\text { mandibular prognathism. }\end{array}$ \\
\hline
\end{tabular}

Table 3: Type of imaging and analysis performed and results by region: nasal, labial and mental.

\begin{tabular}{|c|c|c|c|c|}
\hline Authors / Year & $\begin{array}{l}\text { Imaging/Analysis } \\
\text { method }\end{array}$ & Labial results & $\begin{array}{c}\text { Nasal and para-nasal } \\
\text { results }\end{array}$ & Chin area Results \\
\hline Andreas Fetal 2015[22] & $\begin{array}{l}\text { Lateral cephalometry } \\
\mathrm{T} 0 \text { and } \mathrm{T} 1=6 \text { months } \\
\text { later. }\end{array}$ & $\begin{array}{l}\text { Gp1: [+] U.L.-Line E. of } 2,3 \mathrm{~mm} \\
\text { [-] l'épaisseur d'U.L. of } 0,9 \mathrm{~mm} \\
\text { Gp2: [+] (U.L..-LineE) of } 5,9 \mathrm{~mm} \\
\text { [-] U.L. thickness. of 2,6mm } \\
{[+] \quad \text { U.L. length }} \\
{[+]}\end{array}$ & $\begin{array}{l}\text { - Gp1, Gp2: Nasal } \\
\text { Proéminence } \\
\text {-Light [+] naso-labial angle. }\end{array}$ & [+] Cervical-chin distance. \\
\hline $\begin{array}{c}\text { Kyung-A Kim2019 } \\
{[23]}\end{array}$ & $\begin{array}{l}\text { Cephalometry before, } \\
\text { after } 6 \text { months, } 1 \\
\text { year and } 3 \text { years. }\end{array}$ & [-] L.L, U.L. thickness. & -no change in nasal projection & - \\
\hline $\begin{array}{c}\text { Siamak } \\
\text { hemmotpoor2016, [24] }\end{array}$ & $\begin{array}{l}\text { Lateral cephalometry } \\
\mathrm{T} 0 \text { and } \mathrm{T} 1=6 \text { months } \\
\text { after surgery }\end{array}$ & Ratio L.L- L.i. =77/100 & - & $\begin{array}{l}- \text { Ratio B'-B=97\% } \\
\text {-Pog-Pog'=97\% }\end{array}$ \\
\hline $\begin{array}{l}\text { Stéfan 2018, } \\
\text { allemangne[30] }\end{array}$ & 2D Photographs & $\begin{array}{l}{[+] \text { superior cutaneous labial height. }} \\
{[-] \text { cutaneous L.L. height and }} \\
\text { superior vermilion height. }\end{array}$ & {$[+]$ nasal width, alar base. } & - \\
\hline $\begin{array}{c}\text { Su-Kwon Kim } \\
2009,[31] \\
\end{array}$ & $\begin{array}{c}\text { Cephalometry + } \\
\text { lateral photography }\end{array}$ & $\begin{array}{l}\text { [+] U.L. length } \\
\text { [-] L.L Length }\end{array}$ & - & [-] labio-mentalangle \\
\hline Lun-Jou Lo 2018[32] & $\begin{array}{l}\text { Cephalogram before } \\
\text { and after } 6 \text { months }\end{array}$ & -Ratio L.L/ L.I. $=86 / 100$ & - & -Ratio Pog-Pog' $=90 \%$ \\
\hline
\end{tabular}

Pts: Patients, Gp: group, BSSO: Bilateral sagittal split osteotomy, Mvt: Movement, LL: Lower lip, UL: Upper lip, L.I: Lower incisor, Mand.: Mandibular, Max.: Maxilla, B: bone point, B ': cutaneous point B, Pog: Bone pogonion, Pog ': Cutaneous pogonion, Me: Chin, CBCT: cone beam computed tomography, 2D: two dimension, 3D: three dimension, [+]: Increase, [-]: Decrease. 